\title{
Transgenic traits in the cotton crop in Brazil: a review
}

\author{
Juan Piero Antonio Raphael
}

Universidade Estadual Paulista - UNESP, Faculdade de Ciências Agronômicas, Departamento de Produção e Melhoramento Vegetal, Botucatu, SP. E-mail: juanpiero1@gmail.com

\begin{abstract}
Over the last years, the cotton (Gossypium hirsutum L.) crop in Brazil has been substantially modified by a large-scale introduction of biotechnologically-based resources. In this work, a general review on the technical principles and the current status regarding transgenic traits developed for cotton is presented. The use of transgenic cotton, which contains genes isolated from other species, has been increasingly frequent, occupying more than $80 \%$ of the crop production area in Brazil in 2017. The development of transgenic cotton is costly and time-consuming, and is concentrated in a few owner groups. Current generations of Bt protoxins isolated from Bacillus thuringiensis ("Cry" and "Vip" proteins) for control of lepidopteran insects and genes conferring tolerance to glyphosate (cp4epsps and 2mepsps) and ammonium glufosinate (pat and bar) are included as products commercially available for growers. Events for tolerance to the herbicides 2,4-D and dicamba, although already developed, require regulatory authorizations in Brazil, and, probably, will be available for commercialization in the coming years. The combination of several transgenic traits (stacked-traits) within an individual genotype is an increasing tendency for new transgenic cultivars to be launched. More recently, promising studies involving transgenic plants have been conducted to obtain resistance to diseases, tolerance to abiotic stresses, and improvements in fiber and seed properties, which may result in release of new traits in the future.
\end{abstract}

Keywords: breeding; Gossypium hirsutum; genetically modified organisms; herbicide; pest management.

\section{Tecnologias transgênicas na cultura do algodoeiro no Brasil: revisão}

\section{Resumo}

A cultura do algodoeiro (Gossypium hirsutum L.) tem sofrido importantes modificações nos últimos anos no Brasil devido à introdução em larga de escala de recursos provenientes de biotecnologia. Neste trabalho é apresentada uma revisão geral sobre os princípios técnicos e o status atual relacionados a eventos transgênicos desenvolvidos para o algodoeiro. A utilização de algodoeiro transgênico, que contém genes isolados de outras espécies, tem sido cada vez mais frequente, ocupando mais de $80 \%$ das áreas destinadas à cultura no Brasil no ano de 2017. O desenvolvimento de variedades transgênicas é um processo demorado e de custo elevado, e está concentrado em poucos grupos detentores. Entre produtos comercialmente disponíveis aos produtores incluem-se gerações atuais de protoxinas Bt isoladas de Bacillus thuringiensis (proteínas "Cry" e "Vip") para controle de insetos lepidópteros e genes que conferem tolerância aos herbicidas glifosato (cp4epsps e 2mepsps) e glufosinato de amônio (pat e bar). Eventos de tolerância aos herbicidas 2,4-D e dicamba, embora já tenham sido desenvolvidos, necessitam de autorizações regulatórias no Brasil e devem estar disponíveis para comercialização nos próximos anos. A combinação de diversos produtos transgênicos em um mesmo genótipo (produtos piramidados) é uma tendência crescente para os próximos cultivares a serem lançados. Mais recentemente, foram realizados estudos promissores envolvendo transgenia para obtenção de resistência a doenças, tolerância a estresses abióticos e melhorias em propriedades da fibra e da semente, os quais podem resultar no fornecimento de novos eventos futuramente.

Palavras-chave: melhoramento genético; Gossypium hirsutum; organismos geneticamente modificados; herbicida; manejo de pragas. 


\section{Introduction}

The large-scale introduction of biotechnologically-based resources has recently modified cotton (Gossypium hirsutum L.) crop in Brazil, mainly as a consequence of adjustments in field operational procedures to manage transgenic cultivars. Biotechnology may be defined as any technological application which uses organisms or biological systems to make or modify products and processes for a specific use (BRASIL, 1994). Although this procedure is not recent, the DNA manipulation with advanced tissue culture techniques became a key scientific resource for breeding research only a few decades ago. There are currently two major study areas concerning biotechnology for cotton. The first is genomics, whose purpose is to identify genes, mainly with molecular markers. In general, molecular markers have been used to identify genes that control important agronomic traits. The second is genetic engineering, which involves introduction of DNA with non-original genes into cells to produce transgenic plants (BARROSO et al., 2015).

During the 1970s and 1980s, cotton was traditionally grown in Brazil in small farms and harvested by handpicking in northeastern, southeastern and southern regions. In the mid1980s, boll weevil became a major pest, decreasing lint yield and leading to a reduction in cotton areas in traditional regions, mainly in the Northeast. From the mid-1990s onwards, the traditional cotton areas in the Southeast and South decreased and were gradually replaced by highly mechanized large-scale production in big farms in the Brazilian Cerrados. Since then, cotton productivity has gradually increased as a result of the development of adapted cultivars and new management strategies. Over the last decade, the release of transgenic technologies and the increasing use of cotton as a secondseason crop have consolidated its production in the tropical Cerrados. The average seed cotton yield in Brazil currently exceeds $4000 \mathrm{~kg} \mathrm{ha}^{-1}$ and is one of the greatest in the world. Until early 1990s, average yields of $2000 \mathrm{~kg} \mathrm{ha}^{-1}$ had not been reached (CONAB, 2019).

The development of transgenic technologies became a complementary strategy in plant breeding, providing efficient and previously unattainable tools for crop management. These innovations have rapidly spread among cotton growers due to crucial operational advantages which reduce laboring and phytosanitary costs, and minimize risks of yield and fiber-quality losses. One of the first commercial transgenic crops was the bromoxyniltolerant cotton, released in the United States in 1995 to control some broadleaf weeds, but this product was discontinued in 2004 for economic reasons. Bollgard ${ }^{\circledR}$ cotton was launched in 1996 to control some lepidopteran pests. In 1997, the first-generation of tolerant-glyphosate cotton was released in the United States (DUKE, 2014). Since then, different traits have been developed by companies and the use of transgenic products has increased worldwide. In 2017, approximately 24.1 million hectares of transgenic cotton were planted worldwide, which corresponded to $79.8 \%$ of the total area of 30.2 million hectares (ISAAA, 2017), with significant occupation rates in some of the main producing countries such as China (95\%), India (93\%), U.S.A. (96\%) and Australia $(100 \%)$, according to recent estimates (ISAAA, 2017).

The increase in planted area in Brazil has been effective only since 2010, when some of modern traits such as Liberty Link $^{\circledR}$, Widestrike ${ }^{\circledR}$ and $B 2 R F^{\oplus}$ were released in Brazilian cultivars. The adoption of genetically modified cultivars in Brazil was raised from 145,000 ha $(18 \%)$ in the $2009 / 2010$ season (JAMES, 2009) to 940,000 ha $(84 \%)$ in the $2016 / 2017$ season (ISAAA, 2017), an increase of $520 \%$ in the total cotton-grown area. From 1996 to 2012, genetically-transformed traits provided an average farm income of US\$ 91.00 per hectare in Brazil (BROOKES; BARFOOT, 2014), whereas average profit margins of 1.20 for every $\mathrm{R} \$ 1.00$ invested in acquisition of transgenic seeds were reported in the 2013/2014 season (CÉLERES, 2015). Field assessments in the 2014/2015 season showed that stacked GM cultivars resulted in cost reduction of $10 \%$, with expressive savings in insecticide (44\%) and herbicide (57\%) applications (FIGUEIREDO FILHO, 2015).

Taking into account the importance of transgenic cultivars, this review presents and discusses specific issues regarding the use of genetic engineering in the cotton crop in Brazil, and future perspectives related to its research and applications.

\section{Development of a transgenic cultivar}

Prado et al. (2014) conducted an extensive review on the development of 
transgenic plants and described several phases involved from the initial concept to the release of the commercial product. The whole process may be summarized in consecutive procedures as follows: product concept (1), gene discovery (2), evaluation (3), event selection (4), variety development (5), regulatory process (6), field production (7), and commercial release (8). These procedures are distributed in five main phases: gene discovery and identification, genetic transformation, early development, advanced development, and prelaunch and launch. The authors indicate that the introduction of a new transgenic cultivar is a long-term investment that requires, approximately, an average estimated cost of 136 million dollars and 13 years from product concept to product launch. The cost of conducting regulatory safety evaluations, securing global registration, and authorizations was estimated to average 35 million dollars for genetically engineered (GE) crops introduced between 2008 and 2012. The development process comprises several consecutive steps, each taking between two and five years, with some activities overlapping different phases. Each phase requires a cost ranging from 10 to 46 million dollars.

The early developmental steps involve discovery and identification of candidate genes, which are then introduced into the target plant. Prior to transformation of host plants, advanced bioinformatics resources are used to detect amino acid sequences that are homologous to toxins. Afterwards, events that exhibit agronomic performance similar to or exceeding commercial standards are identified and selected. An event, in this context, is defined as a transgenic line regenerated from transformed cells. A next phase involves rigorous and strategic assessment of the food and environmental security of the GE crops. The end of the process is constituted by a phase of regulatory submissions and prelaunch. The last phases also include additional regulatory data generation and agronomic performance assessments (PRADO et al., 2014). Overall, the development of the marketed seeds is accompanied by a quality control program to ensure transgenic identity and purity of materials used in product tests, in the development of regulatory documents for government compliance, and in seed multiplication procedures for commercial release (MUMM; WALTERS, 2001).
Genetic transformation is commonly performed using the soil bacteria Agrobacterium tumefaciens or particle bombardment (biolistics), with the former the most applied. The transformation is followed by callus regeneration, which is multiplied and assessed for the introduced trait prior to introgression into cultivars. In breeding programs, the trait is integrated into a new plant variety or transferred by backcross techniques into developed lines and cultivars. In cotton breeding programs conducted in Brazil, the backcross approach is predominant, so that transgenic traits are transferred from donor cultivars carrying one or more desired genes to commercial varieties and advanced lines with high agronomic performance. Some of the agronomic traits currently sought for cotton in Brazilian breeding programs are high adaptability, high lint yield $\left(>2000 \mathrm{~kg} \mathrm{ha}^{-1}\right)$, high lint percentage (> $42 \%)$, high fiber quality, resistance to bacterial, fungal and viral diseases (bacterial blight, blue disease, ramularia leaf spot and ramulosis), and resistance to root-knot and reniform nematodes (FREIRE et al., 2015). Backcrossing has shown operational advantages for the cotton crop since generally the gene donor plant was not developed within the country, thus making the introgression into cultivars and lines already adapted to Brazilian conditions a faster procedure. Concomitantly, this method provides additional security if an event becomes obsolete, as occurred with the first generation of glyphosate-tolerant cultivars, because a second generation of the trait is introgressed into a non-genetically engineered variety or line. A further advantage is related to the dominant monogenic inheritance for tolerance to glyphosate (PADGETTE et al., 1995) and ammonium glufosinate (SANKULA et al., 1998), and dominant monogenic or digenic for resistance to lepidopteran pests (RASHID et al., 2008, WU et al., 2003). These properties result in high expression levels of the desired genes in the following generations obtained by backcrossing.

The ideal breeding strategy is to produce an isoline of the selected germplasm containing the target trait with no other donor genetic material. Efforts are made to minimize the presence of additional donor-linked gene fractions that cause negative agronomic impacts on the first backcross generation (PRADO et al., 2014). The backcrossing phase may involve several self-pollination generations. The use of molecular markers can reduce the number of 
progeny generations necessary to recover the parent germplasm of the advanced lines with the genes of interest introgressed from the donor plant (MUMM; WALTERS, 2001). Some breeding research results have revealed that molecular marker-assisted enrichment techniques increase the frequency of selected alleles, allowing large reductions in minimum population size for recovery of target homozygous genotypes (BONNETT et al., 2005). Computer simulation has also been used in single or multiple trait integration to optimize backcrossing strategies, including the number of backcrosses and additional procedures involved, for recovery of lines with target event loci in a homozygous state (PENG et al., 2014).

In Brazil, transgenic traits currently authorized for commercialization include tolerance to herbicides (glyphosate, ammonium glufosinate, and dicamba) and resistance to some lepidopteran pests (Table 1). These single-trait products have been combined to generate multiple genetic engineered traits, also known as "stacked" traits. The trade names of genetically engineered products found in currently registered cotton cultivars and their respective owner companies are shown in Table 2 . There are currently 83 transgenic cotton cultivars registered in the National Register of Cultivars (BRASIL, 2018): 3 RR, 14 RF, 2 Bollgard, 4 LL, 9 WS, $3 \mathrm{GL}, 7 \mathrm{GLT}, 4 \mathrm{BGRR}, 36 \mathrm{~B} 2 \mathrm{RF}$, and $1 \mathrm{GLTP}$, as shown in Table 2. Sixty four transgenic cultivars were registered since 2013 (approximately 75\% of the total). To date, 62 transgenic cultivars (approximately 75\%) were registered by three owners: Monsanto Company (37.3\%), Unisoja S/A (20.5\%), and Bayer Crop Science (16.9\%). Thirtytwo transgenic cultivars were registered since 2015, 17 of which containing stacked genes for tolerance to herbicides and resistance to insects (BRASIL, 2018).

Table1. Transgenic products authorized by CTNBio for commercialization in Brazil for the cotton crop (CIB, 2018).

\begin{tabular}{|c|c|c|c|c|}
\hline Trade name & $\begin{array}{l}\text { Owner } \\
\text { company }\end{array}$ & Function & Gene(s) & $\begin{array}{l}\text { Year of } \\
\text { approval }\end{array}$ \\
\hline Bollgard & Monsanto & $\mathrm{INS}^{1}$ & cry1Ac & 2005 \\
\hline Liberty Link & Bayer & $\mathrm{GLU}^{2}$ & bar & 2008 \\
\hline Roudoup Ready & Monsanto & $\mathrm{GLY}^{3}$ & cp4 epsps (aroA:CP4) & 2008 \\
\hline Widestrike & Dow & INS & cry $1 F+c r y A c$ & 2009 \\
\hline Bollgard II & Monsanto & INS & $\operatorname{cry} 1 A c+c r y 2 A b 2$ & 2009 \\
\hline $\begin{array}{c}\text { Roudoup Ready + } \\
\text { Bollgard }\end{array}$ & Monsanto & GLU+INS & $\begin{array}{c}c p 4 \text { epsps } \\
\text { (aroA:CP4)+cry1Ac }\end{array}$ & 2009 \\
\hline Glytol & Bayer & GLY & 2 mepsps & 2010 \\
\hline Roundup Ready Flex & Monsanto & GLY & cp4 epsps (aroA:CP4) & 2011 \\
\hline Twinlink & Bayer & GLU+INS & bar + cry $1 A b+c r y 2 A e$ & 2011 \\
\hline Glytol+Liberty Link & Bayer & GLY+GLU & $2 m e p s p s+b a r$ & 2012 \\
\hline Glytol + Twinlink & Bayer & GLY+GLU+INS & $\begin{array}{l}2 \text { mepsps+bar+ } \\
\text { cry } 1 A b+c r y 2 A e\end{array}$ & 2012 \\
\hline $\begin{array}{c}\text { Roundup Ready Flex+ } \\
\text { Bollgard II }\end{array}$ & Monsanto & GLY+INS & $\begin{array}{l}\text { cp4 epsps (aroA:CP4) } \\
+ \text { cry } 1 A c+c r y 2 A b 2\end{array}$ & 2012 \\
\hline $\begin{array}{l}\text { Roundup Ready } \\
\text { Flex }+ \text { Bollgard } 3\end{array}$ & Monsanto & GLY+INS & $\begin{array}{c}\text { cp4 epsps(aroA:CP4) } \\
+ \text { cry1Ac+cry } 2 A b 2+ \\
\text { vip3A }\end{array}$ & 2016 \\
\hline $\begin{array}{l}\text { Glytol + Twinlink + } \\
\text { COT102 }\end{array}$ & Bayer & GLY+GLU+INS & $\begin{array}{c}2 \text { mepsps+bar+ } \\
\text { cry } 1 A c+c r y 2 A e+ \\
\text { vip3A }\end{array}$ & 2017 \\
\hline MON 88701 & Monsanto & GLU+DIC ${ }^{4}$ & $p a t+d m o$ & 2017 \\
\hline
\end{tabular}

\footnotetext{
${ }^{1}$ INS: resistance to insects (lepidopteran pests).

${ }^{2} \mathrm{GLU}$ : tolerance to ammonium glufosinate.

${ }^{3} \mathrm{GLY}$ : tolerance to glyphosate.

${ }^{4}$ DIC: tolerance to dicamba.
} 
Table 2. Trade names of transgenic traits released for cotton in Brazil and cultivars registered in the National Register of Cultivars (BRASIL, 2018).

\begin{tabular}{|c|c|c|c|}
\hline Abbreviation & Trade name & Owner company & $\begin{array}{c}\text { Number of registered } \\
\text { cultivars }\end{array}$ \\
\hline $\mathrm{RR}$ & Roundup Ready & Monsanto Company & 3 \\
\hline RF or RR Flex & Roundup Ready Flex & Monsanto Company & 14 \\
\hline Bollgard or BG & Bollgard & Monsanto Company & 2 \\
\hline BGRR & Bollgard + Roundup Ready & Monsanto Company & 4 \\
\hline $\mathrm{B} 2 \mathrm{RF}$ & $\begin{array}{c}\text { Bollgard II + Roundup Ready } \\
\text { Flex }\end{array}$ & Monsanto Company & 36 \\
\hline WS & Widestrike & Dow AgroSciences & 9 \\
\hline $\mathrm{LL}$ & Liberty Link & Bayer Crop Science & 4 \\
\hline $\mathrm{GL}$ & Glytol + Liberty Link & Bayer Crop Science & 3 \\
\hline GLT & $\begin{array}{c}\text { Glytol + Liberty link + } \\
\text { Twinlink }\end{array}$ & Bayer Crop Science & 7 \\
\hline GLTP & $\begin{array}{l}\text { Glytol + Lyberty link + } \\
\text { Twinlink + COT102 }\end{array}$ & Bayer Crop science & 1 \\
\hline
\end{tabular}

\section{Transgenic cotton for herbicide tolerance Tolerance to glyphosate}

Glyphosate is an herbicide that works by competitive inhibition of the enzyme 5-enolpyruvyl shikimate-3-phosphate synthase (EPSPs), which catalyzes an essential step in the amino acid biosynthetic pathway (DANIELL et al., 1998). Tolerance to glyphosate was introduced into some crops, such as soybean, cotton, and canola by the expression of a EPSPs variant from Agrobacterium sp. CP4 (CP4-EPSPs), that binds glyphosate less efficiently. The first glyphosatetolerant cotton product, Roundup Ready ${ }^{\circledR}$ ("MON $1445^{\prime \prime}$ ), was developed utilizing this CP4-EPSPs and commercially launched in 1997 (CERNY et al., 2010). This gene was named cp4-epsps.

Due to insufficient expression of CP4EPSPs in male reproductive tissues, glyphosate applications had to be made up to the four-true leaf stage of growth. When sprayed later, there was a glyphosate accumulation in toxic concentrations that impaired pollen development, resulting in low fertilization and higher boll losses. In order to produce events with complete constitutive expression, two $c p 4$ epsps gene cassetes and other oriented regulatory sequences were inserted by genetic transformation into cotton. As result, a new event was selected and designated as "MON 88913". The MON 88913 trait was named as Roundup Ready Flex ${ }^{\circledR}$ and commercialized for the first time in 2006 (RAO, 2015). In Brazil, the approval for commercialization was obtained in 2011 and the first cultivars were registered in 2012. This second generation of the cp4-epsps gene enabled glyphosate applications after the 4leaf stage with no yield losses (HUFF et al., 2010; MAY et al., 2004). Another trait, named Glytol ${ }^{\circledR}$ and produced by Bayer Crop Science also for glyphosate tolerance, was authorized in 2008 and 2010 for commercial use in the USA and Brazil, respectively. The tolerance was provided by the expression of the modified gene 2-mepsps obtained by genetic transformation techniques in maize (Zea mays L.) tissues. This product also provides no restrictions on the time of herbicide application.

In Brazil, species such as Conyza canadensis (horseweed), Digitaria insularis (sourgrass), Lolium multiflorum (Italian ryegrass), and Chloris elata (tall windmill grass) have shown tolerance to glyphosate. As glyphosate is a lowcost and efficient herbicide, the adoption of tolerant soybean, corn, and cotton by growers has been frequent. In this regard, crop management should involve the preservation of the technology, using herbicides of different modes of action and monitoring the emergence of tolerant weeds. Among other species spread worldwide, tolerance to glyphosate is documented for Lolium perenne and Urochloa panicoides in Australia, Eleusine indica in Malaysia, and Conyza canadensis (Delaware, California e Ohio) and Amaranthus palmeri 
(Georgia) in the United States (LEMAUX, 2009). Tolerance to glyphosate by palmer amaranth (Amaranthus palmeri) has been one of the biggest problems in agricultural areas of the USA. Moghadam et al. (2013) found an increase in the number of genomic copies of EPSPs in tolerant plants of this species, which reduced shikimate accumulation. The authors also observed that this tolerance does not follow a monogenic pattern of inheritance. The occurrence of Amaranthus palmeri in Brazil was recently reported (ANDRADE JUNIOR et al., 2015).

The introduction of cultivars carrying tolerance genes to herbicides of different modes of action may delay or decrease the occurrence of tolerant weeds (LEMAUX, 2009). The use of Liberty Link $^{\circledast}$ varieties tolerant to ammonium glufosinate and the development of events tolerant to dicamba and 2,4-D are steps in this direction.

\section{Tolerance to ammonium glufosinate}

Tolerance to ammonium glufosinate has been provided by either pat or bar genes, isolated from the soil bacteria Streptomyces hygroscopicus and Streptomyces viridochromogenes, respectively (GREEN; OWEN, 2011). Ammonium glufosinate inhibits the enzyme glutamine synthetase, which catalyzes the reaction of ammonium with glutamate to form glutamine during nitrogen assimilation reactions. As a consequence, there is an accumulation of ammonia in the chloroplasts, resulting in phytotoxic effects. Both pat and bar genes encode $\mathrm{N}$-acetyltransferases, which convert the active portion of the herbicide to a non-toxic form through acetylation. In Brazil, an ammonium glufosinate tolerance product owned by Bayer Crop Science, known as Liberty Link $^{\circledR}$ (bar gene), has been commercialized since the end of the last decade, when the cultivars FM 966 LL and FM 951 LL were launched. In 2017, a product tolerant to dicamba also carrying the pat gene that confers tolerance to ammonium glufosinate (MON 88701) was approved by the Brazilian National Technical Biosafety Committee (CTNBio).

Cotton growers have also used ammonium glufosinate on cultivars bearing the Widestrike ${ }^{\circledR}$ trait, developed for resistance to some lepidopteran pests. During the process of introducing this trait in cotton, the gene encoding phosphinothricin acetyltransferase (pat gene) was also inserted as a selective marker to aid in selection of transformed plants for resistance to insects (OGTR, 2009). However, Dow AgroSciences, the owner company of the Widestrike ${ }^{\circledR}$ product, does not recommend postemergence applications of ammonium glufosinate. Experiments have been conducted to evaluate the susceptibility of Widestrike ${ }^{\circledR}$ cultivars to ammonium glufosinate injuries. Sweeney and Jones (2015) observed that WS cultivars showed $11 \%$ more cumulative leaf injury (percent leaf chlorosis + percent leaf necrosis) than sprayed Liberty Link ${ }^{\circledR}$ cultivars. However, the authors found no differences in lint yield between sprayed Widestrike ${ }^{\circledR}$ or Liberty Link ${ }^{\circledR}$ cultivars and their respective controls.

\section{Tolerance to 2,4-D and dicamba}

In the United States, multiple-tolerance traits have been developed for herbicides, including hormonal ones, such as 2,4-D and dicamba, obtained from bacterial genes. Cotton with simultaneous tolerance to glyphosate, ammonium glufosinate and 2,4-D was developed by Dow AgroSciences (BARROSO et al., 2015). Merchant et al. (2014) argues that growing a cotton cultivar tolerant to glufosinate and 2,4-D may be an important management tool to control Amaranthus palmeri in the United States. The introduction of the trait for 2,4-D tolerance into cotton consisted of transferring the $t F d A$ gene from the bacterium Cupriavidus necator, which codes for a dioxygenase catalyzing the degradation of 2,4-D to 2,4-dichlorophenol (LAURENT et al., 2000).

Tolerance to dicamba was obtained from a gene cloned from the soil bacterium Stenotrophomonas maltophilla that encodes for dicamba monooxygenase (DMO), an enzyme that deactivates the herbicide. This gene was named dmo. The dicamba-tolerance event was developed by Monsanto Company and included in a stacked-trait product also containing tolerance to glyphosate and ammonium glufosinate, marketed as "Roundup Ready ${ }^{\circledR}$ Xtend Crop System" (BARROSO et al., 2015). In the United States, the cotton tolerant to dicamba + ammonium glufosinate + glyphosate from Monsanto Company was approved by the USDA for commercialization in 2015. In Brazil, the documentation recently approved by CTNBio of the product containing the $d m o$ and pat genes (MON 88701) continues to be processed for next regulatory authorizations. In turn, the cotton tolerant to 2,4-D + glufosinate from Dow 
AgroSciences (Enlist ${ }^{\mathrm{TM}}$ ) was launched in the United States in 2016 bearing additional stacked genes for tolerance to glyphosate and resistance to lepidopteran pests. In Brazil, documentation on the trait for tolerance to 2,4-D was submitted in 2017 and is pending approval by CTNBio. Cotton cultivars tolerant to 2,4-D and dicamba will likely be launched in Brazil in the next years, but there is no exact prediction at the moment.

However, the introduction of combined tolerance to both glyphosate and 2,4-D into Brazilian cultivars has increasingly became a technical concern among growers and researchers since these herbicides have been widely used for cotton stalk destruction during the last decade (ANDRADE JUNIOR et al., 2017). Volunteer plants tolerant to glyphosate have already become an increasing problem for crop management over the last years. Non-destroyed cotton plants and stalks may difficult field operations of subsequent crops tolerant to glyphosate and serve as hosts for boll weevil (Anthonomus grandis) survival and reproduction. As a consequence, cotton stalk destruction will only be possible through application of other active ingredients or through a mechanical method, a non-recommended practice for soil conservation. The occurrence of plants from previous glyphosate-tolerant crops has also been observed in cotton fields, which may require new herbicide management approaches.

\section{Transgenic cotton for insect resistance}

The commercially most important commercial traits for resistance to insects are carriers of Cry proteins, obtained from the bacterium Bacillus thuringiensis (Bt toxins). Some Bt proteins were called "Cry" because they exist as crystals within the bacterium, which produces lethal toxins (delta-endotoxins) to some species of insects (LEMAUX, 2009). The first generation of crops carrying this transgenic trait (Bollgard $\left.{ }^{\circledR}\right)$ had only one toxin in each plant, Cry1Ac. A second generation, seeking to extend resistance to a greater number of species, involved the combination of two or more toxins in a single plant with different modes of action. In the U.S.A., Bollgard $\|{ }^{\circledR}$ cotton bearing both $c r y 1 A c$ and $c r y 2 A b 2$ genes was commercially introduced in 2003. The stacked-trait product had enhanced toxic effects so that other insects were controlled, such as some Spodoptera species and other similar secondary pests. The synergism between the Cry1Ac and Cry2Ab toxins also provided some control of Helicoverpa armigera (WEI et al., 2015). This worm had not been affected by the first Bt cotton bearing only the cry1Ac gene (JIN et al., 2015, TABASHNIK et al., 2008). In addition, the products Widestrike ${ }^{\circledR}$ (Cry1Ac + Cry1F proteins), developed by Dow AgroSciences, and, more recently, Twinlink ${ }^{\circledR}$ (Cry1Ab + Cry2Ae proteins), by Bayer Crop Science, were launched. Monsanto Company and Bayer Crop Science added the vip3A gene to the cry genes of their respective previous stacked traits, Bollgard $\|^{\circledast}$ and Twinlink $^{\oplus}$, to create "Bollgard ${ }^{\circledR} 3^{3}$ and "Twinlink ${ }^{\circledR}+$ COT 102", respectively (Table 1 ), which are not yet available in Brazilian commercial cotton cultivars. Species controlled by each of the traits marketed for cotton in Brazil are shown in Table 3.

According to Ferré and Rie (2009), the toxic pathway of "Cry" proteins involves several steps: on ingestion by susceptible insects, crystals are solubilized and protoxins are released. These protoxins are then processed by midgut proteases into a protease-resistant core fragment, the toxin, which passes through the peritrophic membrane and binds to a specific receptor located on the brush border membrane of midgut cells. Binding, followed by insertion of the toxin into the membrane, results in pore formation, cell lysis, and, eventually, insect death. 
Table 3. Lepidopteran pests controlled by transgenic traits containing "Cry" protoxins in cotton cultivars commercialized in Brazil (2018).

\begin{tabular}{l}
\multicolumn{1}{c}{ Bollgard (Cry1Ac) } \\
\hline Alabama argilacea (Cotton leaf worm) \\
Heliothis virenscens (Tobacco budworm) \\
Pectinophora gossypiella (Pink bollworm) \\
\hline \multicolumn{1}{c}{ Bollgard II (Cry1Ac+Cry2Ab2) } \\
\hline Alabama argilacea \\
Heliothis virenscens \\
Pectinophora gossypiella \\
Chrisodeixis includens (Soybean looper) \\
Spodoptera spp. \\
Helicoverpa spp.
\end{tabular}

\begin{tabular}{l}
$\quad$ Widestrike $(\mathbf{C r y} \mathbf{A} \mathbf{A c}+\mathbf{C r y 1 F})^{3}$ \\
\hline Alabama argilacea \\
Heliothis virenscens \\
Pectinophora gossypiella \\
Chrisodeixis includens \\
Spodoptera spp.
\end{tabular}

\begin{tabular}{l}
\hline \multicolumn{1}{c}{ Twinlink (Cry1Ac+Cry2Ae) ${ }^{4}$} \\
\hline Alabama argilacea \\
Chrisodeixis includens \\
Heliothis virenscens \\
Pectinophora gossypiella \\
Spodoptera spp. \\
Helicoverpa spp.
\end{tabular}

\footnotetext{
${ }_{1}^{1}$ Monsanto Company: http://www.bollgard2rrflex.com.br/tecnologia-bollgard (accessed $20 \mathrm{Jul}$. 2018).

${ }^{2}$ Monsanto Company: http://www.bollgard2rrflex.com.br/tecnologia-bollgard-ii-rr-flex (accessed 20 Jul. 2018).

${ }^{3}$ Dow Agosciences: http://msdssearch.dow.com/PublishedLiteratureDAS/dh 0888/0901b8038088873f.pdf?filepath=br/pdfs..\&fromPage=GetDoc (accessed 20 Jul. 2018).

${ }^{4}$ Bayer Crop Science: https://www.agro.bayer.com.br/-/media/bcs-inter/ws brazil/files/fibermax/boletim tecnico glt.pdf (accessed 20 Jul. 2018).
}

In general, studies suggest that plants carrying more than one Bt protein gene have a higher spectrum of controlled pests and potential to prevent or delay the emergence of resistant insect populations compared to plants with a single Bt protoxin (ZHAO et al., 2003; TABASHNIK et al., 2013). Recessive inheritance of resistance, low frequency of resistance alleles, and refuge areas with non-Bt plants also avoid the development of resistance to transgenic traits in insects (TABASHNIK et al., 2013; WU, 2010). Some recent studies have focused on describing genetic and biochemical properties related to resistance in insects. For example, Fabrick et al. (2014) reported that mutations in a gene encoding a cadherin protein which binds Bt protein were associated with resistance of pink bollworm (Pectinophora gossypiella) to Cry1Ac in India.

In general, three different biochemical mechanisms of resistance to $\mathrm{Bt}$ traits have been observed in insects: proteolytic processing of protoxins, improved repair of damaged midgut cells, and modification of a Cry protein-binding site. However, only one major mechanism has been reported so far for resistance developed under field conditions (reduced binding). Previous studies indicate that the cry gene resistance mechanism in insects involves the reduction of binding of the $\mathrm{Bt}$ protoxin to midgut 
receptors. In all cases of binding site modification, resistance is due to a recessive or partially recessive mutation in a major autosomal gene (FERRÉ; RIE, 2009).

Effects of Bt-protein traits on other cotton pests and soil microorganisms have also been studied. Liu et al. (2005) observed shorter reproductive duration, lower survival rates, lower fecundity potential, and earlier occurrence of first-generation or second-generation peak mortality in aphids (Aphis gossypii) fed with cotton sap from plants expressing both cry $1 A c$ and $\mathrm{CPTI}$ (a trypsin inhibitor encoder) genes. Sarkar et al. (2008) evaluated the soil microbial activity, and found a significant reduction in dehydrogenase activity (17\%) and soil respiration (3.5\%) in a Bt-cotton rhizosphere compared with a non-Bt isoline. These results differ from those obtained by Li et al. (2011), Velmourougane and Sahu (2014), and Zhang et al. (2014), where transgenic cotton had no impact on microbial populations. According to Romeis et al. (2006), the $\mathrm{Bt}$ technology is more specific and provides fewer environmental damages and collateral effects on parasitoids and predators than most insecticides currently used, which justifies its adoption due to the significant reduction in the number of applications. Bennett et al. (2013) report that genetically modified crops can contribute to reduce greenhouse gas emissions, since no-till management practices are facilitated and yield losses are minimized.

There are indications that pest control by Bt proteins in cotton is variable with plant age, plant structure, and environmental stresses. Reduction in Bt-protein concentration in lateseason cotton may be due to overexpression of Bt gene in earlier stages of development (DONG; LI, 2007). Water or low-temperature stresses may decrease the production of insecticide protein, which is likely associated with impaired plant growth (BLAISE; KRANTHI, 2011; ZHOU et al., 2015).

Recently, some studies have been conducted in Brazil by Embrapa Cenargen aiming to develop a transgenic cotton genotype resistant to boll weevil, including gene isolation and expression for cholesterol oxidase biosynthesis; expression of Bt toxins resistant to coleopteran pests, e.g., Cry1la, Cry10Aa, and Cry1b; and expression of protease inhibitors, such as CpTI (MONNERAT et al., 2015). In addition, a Bt product that confers resistance to hemipteran insects (Cry51Aa2) was developed by Monsanto and authorized for food use in Australia and United States, and may be a possible new trait in the coming years (ISAAA, 2019). New multiple stacked-gene Bt events have been authorized for cultivation for insect resistance over the last years and will likely be available in the near future for commercialization in Brazil, United States and Australia.

\section{Other transgenic traits}

Several works attempting to test transgenic cotton for resistance to fungal, viral, and nematode diseases, as well as for tolerance to abiotic stresses have been conducted. The studied fungal diseases are essentially related to soil-living, foliar, and wilt pathogens, including Fusarium spp., Verticillium dahlia, Alternaria alternata, etc. (EMANI et al., 2003; GANESAN et al., 2009; MURRAY et al., 1999; PARKHI et al., 2010; RAJASEKARAN et al., 2005). Transgenic traits for control of cotton leaf curl (CLCuV) virus (HASHMI et al., 2011; SANJAYA et al., 2005) and Rothylenchulus reniformis (PARKHI et al., 2010) have also been examined. Tolerance to drought (YAN et al., 2004; MAQBOOL et al., 2010), lowtemperature (PAYTON et al., 2001; ZHANG et al., 2012), and salt (LIU et al., 2012; LV et al., 2008; PASAPULA et al., 2011; ZHANG et al., 2009) stresses has also been subject of research in transgenic cotton breeding. In addition, genetic engineering techniques have been applied to seek improved fiber properties, such as higher length, strength and insulating capacity (JIANG et al., 2012; JOHN; KELLER, 1996; ZHU et al., 2006), and seed quality, including better oil composition (CHAPMAN et al., 2001; LIU et al., 2002) and elimination of gossypol (MARTIN et al., 2003; SUNILKUMAR et al., 2006). A recent detailed review on results from transgenic cotton developed for resistance to biotic diseases, tolerance to abiotic stresses, and enhanced fiber and seed quality was published by Chakravarthy et al. (2014). Although some successful experimental results have been achieved, there are no reports on these events in Brazilian cotton breeding programs.

\section{Final remarks}

Since transgenic cultivars have been extensively used in Brazilian cotton production areas, a tendency for the number of stacked-trait cultivars to increase is verified. Consequently, taking into account that different crops contain the same tolerance genes, a careless 
management of the new traits may lead to even greater problems with herbicides to control weeds and cotton stalks. Other potential problems are the adaptation of previously secondary pests that can result in subsequent damages; and the migration of pests between successive crops, as verified for some insect species able to attack soybean and cotton plants.

It is also expected that breeding programs will use genetic engineering for purposes other than herbicide tolerance and resistance to lepidopteran pests, such as resistance to diseases, tolerance to drought and low temperatures, and improvements on fiber and seed properties, although these concerns seem not to be the main priority for companies which develop large-scale transgenic researches. In addition, it is possible that genetic engineering techniques contribute in the future to develop technologies for control of the boll weevil, the most important pest of cotton. Studies involving crop system management with transgenic traits will also gain importance in the coming years as a consequence of the increasing area grown with GE cultivars, due to the need of better technical recommendations for new crop rotations and planting-date alterations in some of the main cotton-producing regions of Brazil.

Since the development of transgenic cotton is costly and time-consuming, the traits will likely continue to be provided by few large companies. As cotton is sown over large agricultural areas and seeds with high-priced royalties represent a significant fraction of crop production costs, the launch of transgenic products has been highly profitable. Stacking multiple genes within a single variety can make the seeds even more expensive for growers, which is a compensatory strategy for breeding companies. In addition, since transgenic traits may be introgressed into field-adapted cultivars by backcrossing, operational processes are facilitated once the donor cultivar or line is obtained.

Transgenic materials provide facilitated crop management and decreased operational costs, leading to a significant adoption of the marketed traits by growers of some worldwide major crops. However, long-term management strategies, such as following refuge-area recommendations for Bt plants and applying products with different modes of action for herbicide-tolerance GE traits, are important to preserve these recent technologies for the future.

\section{References}

ANDRADE JUNIOR, E. R.; CAVENAGHI, A. L.; GUIMARÃES, S. C. Destruição química de soqueira em variedades de algodoeiro resistentes ao glifosato - Safra 2016. Cuiabá: Imamt, 2017. 8p. (Circular Técnica, 29). Disponível em: < http://www.imamt.com.br/system/anexos/arqui vos/359/original/circular tecnica edicao29 bx ( 1).pdf?1490875649>. Acesso em: 15 jan. 2019.

ANDRADE JUNIOR, E. R.; CAVENAGHI, A. L.; GUIMARÃES, S. C.; CARVALHO, S. J. P. Primeiro relato de Amaranthus Palmeri no Brasil em áreas agrícolas no estado de Mato Grosso. Cuiabá: Imamt, 2015. 8p. (Circular Técnica, 19). Disponível em:

http://www.imamt.com.br/system/anexos/arqui vos/294/original/circular tecnica edicao19 bx o k.pdf?1434631723>. Acesso em 15 jun. 2018.

BARROSO, P. A. V.; HOFFMANN, L. V.; SUASSUNA, N. D.; FERREIRA, A. C. B. Algodoeiros geneticamente modificados. In: FREIRE, E.C.(Ed.). Algodão no cerrado do Brasil. 3. ed. Brasília: Abrapa, 2015. cap. 22, p. 807-842.

BLAISE, D.; KRANTHI, K. R. Cry1Ac expression in transgenic $B t$ cotton hybrids is influenced by soil moisture and depth. Current Science, v. 101, n. 6, p. 783-785, 2011. Disponível em: http://www.currentscience.ac.in/Volumes/101/0 6/0783.pdf. Acesso em: 25 jul. 2018.

BENNETT, A. B.; CHI-HAM, C.; BARROWS, G.; SEXTON, S.; ZILBERMAN, D. Agricultural biotechnology: economics, environment, ethics, and the future. Annual Review of Environment and Resources, v. 38, p. 249-279, 2013. http://dx.doi.org/ 10.1146/annurev-environ$\underline{050912-124612}$

BONNETT, D. G.; REBETZKE, G. J.; SPIELMEYER, W. Strategies for efficient implementation of molecular markers in wheat breeding. Molecular Breeding, v. 15, p. 75-85, 2005. https://doi.org/10.1007/s11032-004-2734-5

BRASIL. Decreto no 2, de 1994. Aprova o texto da Convenção sobre Diversidade Biológica, assinada durante a Conferência das Nações Unidas sobre 
Meio Ambiente e Desenvolvimento realizada na cidade do Rio de Janeiro, no período de 5 a 14 de junho de 1992. Preâmbulo. Diário Oficial da União, Brasília, DF, 4 fev. 1994. Seção 1, p. 1693, Disponível

em: http://www2.camara.leg.br/legin/fed/decleg/199 4/decretolegislativo-2-3-fevereiro-1994-358280norma-pl.html/. Acesso em: 20 jul. 2018.

BRASIL. Ministério da Agricultura, Pecuária e Abastecimento. Registro Nacional de Cultivares. Brasília, 2018. Disponível em: http://sistemas.agricultura.gov.br/snpc/cultivarw eb/cultivares registradas.php>. Acesso em: 18 jul. 2018.

CÉLERES. Os benefícios econômicos da biotecnologia agrícola no Brasil: 1996/97 2013/14. Uberlândia: Céleres, 2015. Disponível em:

http://www.celeres.com.br/docs/biotecnologia/P ressRelease2014 Economico.pdf. Acesso em: 18 jan. 2019.

CERNY, R. E. et al. Development and characterization of a cotton (Gossypium hirsutum L.) event with enhanced reproductive resistance to glyphosate. Crop Science, v. 50, p. 1375-1384, 2010.

http://dx.doi.org/10.2135/cropsci2009.06.0286

CHAKRAVARTHY, V. S. K.; REDDY, T. P.; REDDY, V. D.; RAO, K. V. Current status of genetic engineering in cotton (Gossypium hirsutum L): an assessment. Critical Reviews in Biotechnology, v. 34, n.2, p.144-160, 2014. http://dx.doi.org/10.3109/07388551.2012.74350 $\underline{2}$

CHAPMAN, K. D.; AUSTIN-BROWN, S.; SPARACE, S. A.; KINNEY, A. J.; RIPP, K. G.; PIRTLE, I. L.; PIRTLE, R. M. Transgenic cotton plants with increased seed oleic acid content. Journal of the American Oil Chemists' Society, v. 78, p. 941947, 2001. http://dx.doi.org/10.1007/s11746001-0368-y

CIB. Conselho de Informações sobre Biotecnologia. Produtos Aprovados. 2018. Disponível em: < https://cib.org.br/produtosaprovados/>. Acesso em: 05 jul. 2018.

CONAB. Série Histórica das safras. 2019. Disponível em: https://www.conab.gov.br/info- agro/safras/serie-historica-das-safras. Acesso em: 10 jan. 2019.

DANIELL, H.; DATTA, R.; VARMA, S.; GRAY, S.; LEE, $S$. B. Containment of herbicide resistance through genetic engineering of chloroplast genome. Nature Biotechnology, v. 16, p. 345-348, 1998. http://dx.doi.org/10.1038/nbt0498-345

DONG, H. Z.; LI, W. J. Variability of endotoxin expression in Bt transgenic cotton. Journal of Agronomy and Crop Science, v. 193, p. 21-29, $2007 . \quad$ https://doi.org/10.1111/i.1439037X.2006.00240.X

EMANI, C. et al. Enhanced fungal resistance in transgenic cotton expressing an endochitinase gene from Trichoderma virens. Plant Biotechnology Journal, v. 1, p. 321-336, 2003. https://doi.org/10.1046/j.1467-

7652.2003.00029.x

FABRICK, J. A.; PONNURAJ, J.; SINGH, A.; TANWAR, R. K.; UNNITHAN, G. C.; YELICH, A. J.; LI, X.; CARRIÉRE, Y.; TABASHNIK, B. E. Alternative splicing and highly variable cadherin transcripts associated with field-evolved resistance of pink bollworm to Bt cotton in India. Plos one, v. 9, n. 5 , 2014.

https://doi.org/10.1371/iournal.pone.0097900

FERRÉ, J.; RIE, J. Biochemistry and genetics of insect resistance to Bacillus thuringiensis. Annual Review of Entomology, v. 47, p. 501-533, 2002. https://doi.org/10.1146/annurev.ento.47.091201 .145234

FIGUEIREDO FILHO, S. A. É possível ter sucesso na produção de algodão BT?: Manejo e custos do algodão convencional na Fazenda São Francisco. In: CONGRESSO BRASILEIRO DO ALGODÃO, 10., 2015, Foz do Iguaçu. Palestras... Abrapa: Brasília, $2015 . \quad$ Disponível em: http://congressodoalgodao.com.br/2015/livrode-resumos2015/palestrantes.htm. Acesso em: 20 jan. 2019.

FREIRE, E. C.; MORELLO, C. L.; FARIAS, F. J. C.; PEDROSA, M. B.; SILVA FILHO, J. L. Melhoramento do algodoeiro: cultivares convencionais e transgênicas para o Cerrado. In: FREIRE, E.C. (Ed.). Algodão no Cerrado do Brasil. 3. ed. Brasília: Abrapa, 2015. cap. 6, p. 151-201. 
GANESAN, M.; BHANUMATHI, P.; KUMARI, K. G.; PRABHA, A. L.; SONG, P. S.; JAYABALAN, N. Transgenic Indian cotton (Gossypium hirsutum L.) harboring rice chitinase gene (chi II) confers resistance to two fungal pathogens. American Joural of Biochemestry and Biotechnology, v. 5, p.63-74, 2009. https://doi.org/10.3844/ajbbsp.2009.63.74

GREEN, J. M.; OWEN, M. D. K. Herbicide-resistant crops: utilities and limitations for herbicideresistant weed management. Journal of Agricultural and Food Chemistry, v. 59, p. 58195829, 2011. https://doi.org/10.1021/jf101286h

HASHMI, J. A.; ZAFAR, Y.; ARSHAD, M. MANSOOR, S.; ASAD, S. Engineering cotton (Gossypium hirsutum L.) for resistance to cotton leaf curl disease using viral truncated AC1 DNA sequences. Virus Genes, v. 42, p. 286-296, 2011. https://doi.org/10.1007/s11262-011-0569-9

HUFF, J. A.; REYNOLDS, D. B.; DODDS, D. M.; IRBY, J. T. Glyphosate tolerance in enhanced glyphosate-resistant cotton (Gossypium hirsutum). Weed Technology, v. 24, p. 289-294, 2010. https://doi.org/10.1614/WT-08-183.1

ISAAA. GM approval database. 2019. Disponível em: http://www.isaaa.org/gmapprovaldatabase/. Acesso em: 10 jan. 2019.

ISAAA. International Service for the Acquisition of Agri-Biotech Application. Global status of commercialized biotech/GM crops in 2017: biotech crop adoption surges as economic benefits accumulate in 22 years. Ithaca, 2017. 143p. (ISAA Brief, n. 53). Disponível em: http://www.isaaa.org/resources/publications/bri efs/53/default.asp. Acesso em: 10 jul. 2018.

JAMES, C. Global status of commercialized biotech/GM crops: 2009. Ithaca: ISAAA, 2009. (ISAAA Brief, n. 41). Disponível em: http://www.isaaa.org/resources/publications/bri efs/41/. Acesso em: 22 jan. 2019.

JIANG, Y.; GUO, W.; ZHU, H.; RUAN, Y. L.; ZHANG, T. Overexpression of GhSusA1 increases plant biomass and improves cotton fiber yield and quality. Plant Biotechnology Journal, v. 10, p. 301-312, 2012. https://doi.org/10.1111/j.14677652.2011.00662.x
JIN, L. ZHANG, H.; LU, Y.; YANG, Y.; WU, K.; TABASHNIK, B. E.; WU, Y. Large-scale test of the natural refuge strategy for delaying insect resistance to transgenic Bt crops. Nature Biotecnology, v. 33, n. 2, p. 169-174, 2015. https://doi.org/10.1038/nbt.3100

JOHN, M. E.; KELLER, G. Metabolic pathway engineering in cotton: biosynthesis of polyhydroxybutyrate in fiber cells. Proceedings of National Academy of Sciences of the United States of America, v. 93, p. 12768-12773, 1996. https://doi.org/10.1073/pnas.93.23.12768

LAURENT, F.; DEBRAUWER, L.; RATHAHAO, E.; SCALLA, R. 2,4-dichlorophenoxyacetic acid metabolism in transgenic tolerant cotton (Gossypium hirsutum). Journal of Agricultural and Food Chemistry, v. 48, p. 5307-5311, 2000. https://doi.org/10.1021/jf990672c

LEMAUX, P. G. Genetically engineered plants and foods: a scientist's analysis of the issues (part II). Annual Review of Plant Biology, v. 60, 511-559, 2009.

https://doi.org/10.1146/annurev.arplant.043008. $\underline{092013}$

LI, X.; LIU, B.; CUI, J.; LIU, D.; DANG, S.; GILNA, B.; LUO, J.; FANG, Z.; CAO, W.; HAN, Z. No evidence of persistent effects of continuously planted transgenic insect-resistant cotton on soil microorganisms. Plant and Soil, v. 339, p. 247 257, 2011. https://doi.org/10.1007/s11104-010$\underline{0572-2}$

LIU, Q.; SINGH, S. P.; GREEN, A. G. High-stearic and high-oleic cottonseed oils produced by hairpin RNA-mediated post-transcriptional gene silencing. Plant Physiology, v. 129, p. 1732-1743, 2002. https://doi.org/10.1104/pp.001933

LIU, X. D.; ZHAI, B. P.; ZHANG, X. X.; ZONG, J. M. Impact of transgenic cotton plants on a nontarget pest, Aphis gossypii Glover. Ecological Entomology, v. 30, p. 307-315, 2005. https://doi.org/10.1111/j.03076946.2005.00690.x

LIU, Y. D; YIN, Z. J; YU, J. W.; LI, J.; WEI, H. L; HAN, $X$. L; SHEN, F. F. Improved salt tolerance and delayed leaf senescence in transgenic cotton expressing the Agrobacterium IPT gene. Biologia 
Plantarum, v. 56, p. 237-246, 2012. https://doi.org/10.1007/s10535-012-0082-6

LV, S.; ZHANG, K.; GAO, Q.; LIAN, L.; SONG, Y.; ZHANG, J. Overexpression of an $\mathrm{H}+$-PPase gene from Thellungiella halophila in cotton enhances salt tolerance and improves growth and photosynthetic performance. Plant Cell Physiology, v. 49, p. 1150-1164, 2008. https://doi.org/10.1093/pcp/pcn090

MAQBOOL, A.; ABBAS, W.; RAO, A. Q.; IRFAN, M.; ZAHUR, M.; BAKHSH, A.; RIAZUDDIN, S.; HUSNAIN, T. Gossypium arboreum GHSP26 enhances drought tolerance in Gossypium hirsutum. Biotechnology Progress, v. 26, p. 2125, 2010. https://doi.org/10.1002/btpr.306

MARTIN, G. S.; LIU, J.; BENEDICT, C. R.; STIPANOVIC, R. D; MAGILL, C. W. Reduced levels of cadinane sesquiterpenoids in cotton plants expressing antisense (+)-delta-cadinene synthase. Phytochemistry v. 62, p. 31-38, 2003. https://doi.org/10.1016/S0031-9422(02)00432-6

MAY, O. L.; et al. Transgenic cotton with improved resistance to glyphosate herbicide. Crop Science, v. 44, p. 234-240, 2004. https://doi.org/10.2135/cropsci2004.2340

MERCHANT, R. M.; CULPEPPER, A. S.; EURE, P. M; RICHBURG, J. S.; BRAXTON, L. B. Salvage palmer amaranth programs can be effective in cotton resistant to glyphosate, 2,4-d, and glufosinate. Weed Techonology, v. 28, p. 316-322, 2014. https://doi.org/10.1614/WT-D-13-00119.1

MOGHADAM, M. M.; SCHROEDER, J.; ASHIGH, J. Mechanism of resistance and inheritance in glyphosate resistant palmer amaranth (Amaranthus palmeri) populations from $\mathrm{New}$ Mexico, USA. Weed Science, v. 61, p. 517-525, 2013. https://doi.org/10.1614/WS-D-13-00028.1

MONNERAT, R.; SANTOS, R. C.; LIMA, L. M.; PINHEIRO, M. P. N.; SILVA, C. R. C.; SOARES, C. M. Uso da transgenia para controle do bicudo-doalgodoeiro. In: BELOT, J. L. (Ed.). O bicudo-doalgodoeiro (Anthonomus grandis BOH., 1843) nos cerrados brasileiros: Biologia e medidas de controle. Cuiabá: IMAmt, 2015. p. 183-211. (Boletim de Pesquisa e Desenvolvimento, n. 2).
MURRAY, F.; LLEWELLYN, D.; MCFADDEN H.; LAST, D.; DENNIS, E. S.; PEACOCK, W. J. Expression of the Talaromyces flavus glucose oxidase gene in cotton and tobacco reduces fungal infection, but is also phytotoxic. Molecular Breeding, v. 5, p. 219-232, 1999. https://doi.org/10.1023/A:1009625801909

MUMM, R. H.; WALTERS, D. S. Quality control in the development of transgenic crop seed products. Crop Science, v. 41, p. 1381-1389, 2001.

https://doi.org/10.2135/cropsci2001.4151381x

OGTR. Risk assessment and risk management plan for DIR 091-Commercial release of cotton genetically modified for insect resistance (WideStrike $^{\mathrm{TM}}$ Insect Protection cotton). 2009. Disponível em: $<$ www.ogtr.gov.au/internet/ogtr/publishing.nsf/c ontent/dir091-3/\$FFLE/dir091rarmp1.pdf>.

Acesso em: 29 jun. 2018.

PADGETTE, S.R. et al. Development, identification, and characterization of a glyphosate-tolerant soybean line. Crop Science, v. 35, p. 1451-1461, 1995. https://doi.org/10.2135/cropsci1995.0011183X0 $\underline{03500050032 x}$

PARKHI, V.; KUMAR, V.; CAMPBELL, L. M.; BELL, A. A.; SHAH, J.; RATHORE, K. S. Resistance against various fungal pathogens and reniform nematode in transgenic cotton plants expressing Arabidopsis NPR1. Transgenic Research, v. 19, p. 959-975, 2010. https://doi.org/10.1007/s11248010-9374-9

PASAPULA, V. et al. Expression of an Arabidopsis vacuolar $\mathrm{H}+$-pyrophosphatase gene (AVP1) in cotton improves drought- and salt tolerance and increases fibre yield in the field conditions. Plant Biotechnology Journal, v. 9, p. 88-99, 2011. https://doi.org/10.1111/j.1467-

7652.2010.00535.x

PAYTON, P.; WEBB, R.; KORNYEYEV, D.; ALLEN, R.; HOLADAY, A. S. Protecting cotton photosynthesis during moderate chilling at high light intensity by increasing chloroplastic antioxidant enzyme activity. Journal of Experimental Botany, v. 52, p. 2345-2354, 2001. https://doi.org/10.1093/jexbot/52.365.2345 
PENG, T.; SUN, X.; MUMM, R. H. Optimized breeding strategies for multiple trait integration: II. Process efficiency in event pyramiding and trait fixation. Molecular Breeding, v. 33, p. 105-115, 2014. https://doi.org/10.1007/s11032-013-99376

PRADO, J. R. et al. Genetically engineered crops: from idea to product. Annual Review of Plant Biology, v. 65, p. 769-790, 2014. https://doi.org/10.1146/annurev-arplant050213-040039

RAJASEKARAN, K.; CARY, J. W.; JAYNES, J. M.; CLEVELAND, T. E. Disease resistance conferred by the expression of a gene encoding a synthetic peptide in transgenic cotton (Gossypium hirsutum L.) plants. Plant Biotechnology Journal, v. 3, p. 545-554, 2005. https://doi.org/10.1111/i.1467$\underline{7652.2005 .00145 . x}$

RAO, V. S. Herbicide-resistant transgenic crops. In: RAO, V. S. Transgenic herbicide resistance in plants. 1. ed. Boca Raton: CRC Press, 2015. chap. 6, p. 267.

RASHID, B.; SALEEM, Z.; HUSNAIN, T.; RIAZUDDIN, $S$. Transformation and Inheritance of Bt Genes in Gossypium hirsutum. Journal of Plant Biology, v. 51, p.248-254 2008.

https://doi.org/10.1007/BF03036123

ROMEIS, J.; MEISSLE, M.; BIGLER, F. Transgenic crops expressing Bacillus thuringiensis toxins and biological control. Nature Biotechnology, v. 24, p. 63-71, 2006. https://doi.org/10.1038/nbt1180

SANJAYA, V. V. S.; PRASAD, V.; KIRTHI, N.; MAIYA, S. P.; SAVITHRI, H. S.; SITA, G. L. Development of cotton transgenics with antisense AV2 gene for resistance against cotton leaf curl virus (CLCUD) via Agrobacterium tumefaciens. Plant Cell, Tissue and Organ Culture, v. 81, p. 55-63, 2005. https://doi.org/10.1007/s11240-004-2777-7

SANKULA, S; BRAVERMAN, M. P.; OARD, J.H. Genetic analysis of glufosinate resistance in crosses between transformed rice (Oryza sativa) and red rice (Oryza sativa). Weed Technology, v. 12, p.209-214, 1998. https://doi.org/10.1017/S0890037X00043700

SARKAR, B.; PATRA, A. K.; PURAKAYASTHA, T. J. Transgenic Bt-cotton affects enzyme activity and nutrient availability in a sub-tropical Inceptisol. Journal of Agronomy and Crop Science, v. 194, p. 289-296, 2008. https://doi.org/10.1111/j.1439037X.2008.00312.x

SUNILKUMAR, G.; CAMPBELL, L. M.; PUCKHABER, L.; STIPANOVIC, R. D.; RATHORE, K. S. Engineering cottonseed for use in human nutrition by tissue specific reduction of toxic gossypol. Proceedings of National Academy of Sciences of the United States of America, v. 103, p. 18054-18059, 2006. https://doi.org/10.1073/pnas.0605389103

SWEENEY, J. A.; JONES, M. A. Glufosinate tolerance of multiple Widestrike and Liberty-Link cotton (Gosspyium hirsutum I.) cultivars. Crop Science, v. 55, p. 403-410, 2015. https://doi.org/10.2135/cropsci2014.03.0175

TABASHNIK, B. E.; BRÉVAULT, T.; CARRIÉRE, Y. Insect resistance to $\mathrm{Bt}$ crops: lessons from the first billion acres. Nature Biotechnology, v. 31, n. 6, p.510-521, 2013. https://doi.org/10.1038/nbt.2597

TABASHNIK, B. E.; GASSMANN, A. J.; CROWDER, D. W.; CARRIÉRE, Y. Reply to field-evolved resistance to Bt toxins. Nature Biotechnology, v. 26, n. 10, p. 1074-1076, 2008. https://doi.org/10.1038/nbt1208-1383b

VELMOUROUGANE, K.; SAHU, A. Impact of transgenic cottons expressing cry $1 A c$ on soil biological attributes. Plant, Soil and Environment, v. 59, p. 108-114, 2013. https://doi.org/10.17221/616/2012-PSE

WEI, J.; GUO, Y.; LIANG, G.; WU, K.; ZHANG, J.; TABASHNIK, B. E.; LI, X. Cross-resistance and interactions between $\mathrm{Bt}$ toxins Cry1Ac and Cry2Ab against the cotton bollworm. Scientific Reports, v.5, n.7714, 2015. https://doi.org/10.1038/srep07714

WU, J. H., ZHANG, X. L.; LUO, X. L.; TIAN, Y. C. Inheritance and segregation of transformants in cotton with two types of insect-resistant genes. Acta Genetica Sinica, v. 30, p. 631-636, 2003. Abstract. Disponível em: https://www.ncbi.nlm.nih.gov/pubmed/1457953 1. Acesso em: 09 jul. 2018. 
WU, K. No refuge for insect pests. Nature Biotechnology, v. 12, p. 1273-1275, 2010. https://doi.org/10.1038/nbt.1718

YAN, J.; HE, C.; WANG, J.; MAO, Z.; HOLADAY, S. A.; ALLEN, R. D.; ZHANG, H. Overexpression of the Arabidopsis 14-3-3 protein GF14 lambda in cotton leads to a "stay-green" phenotype and improves stress tolerance under moderate drought conditions. Plant Cell Physiology, v. 45, p.1007-1014, 2004. https://doi.org/10.1093/pcp/pch115

ZHANG, H.; DONG, H.; LI. W.; SUN, Y.; CHEN, S.; KONG, $X$. Increased glycine betaine synthesis and salinity tolerance in AhCMO transgenic cotton lines. Molecular Breeding, v. 2, p. 289-298, 2009. https://doi.org/10.1007/s11032-008-9233-z

ZHANG, K.; WANG, J.; LIAN, L.; FAN, W.; GUO, N.; LV, S. Increased chilling tolerance following transfer of a betA gene enhancing glycinebetaine synthesis in cotton (Gossypium hirsutum L.). Plant Molecular Biology Reporter, v. 30, p. 1158-1171, 2012. https://doi.org/10.1007/s11105-012-04337

ZHANG, Y. J.; XIE, M.; PENG, D. L. Effects of the transgenic CrylAc and $C p T I$ insect-resistant cotton SGK321 on rhizosphere soil microorganism populations in northern China. Plant, Soil and Environment, v. 60, p. 285-289, 2014. https://doi.org/10.17221/192/2014-PSE

ZHAO, J. Z.; CAO, J.; LI, Y.; COLLINS, H. L.; ROUSH, R. T.; EARLE, E. D.; SHELTON, A. M. Transgenic plants expressing two Bacillus thuringiensis toxins delay insect resistance evolution. Nature Biotechnology, v. 21, p. 1493-1497, 2003. https://doi.org/10.1038/nbt907

ZHOU, G.; WANG, Y.; ZHAI, F.; LU, S.; NIMIR, A. E.; YU, L.; PAN, H.; LV, D. Combined stress of low temperature and flooding affects physiological activities and insecticidal protein content in transgenic Bt cotton. Crop and Pasture Science, v.66, n.7, p.740-746, 2015. https://doi.org/10.1071/CP14012

ZHU, S. W.; GAO, P.; SUN, J. S.; WANG, H. H.; LUO, X. M.; JIAO, M. Y.; WANG, Z. Y.; XIA, G. X. Genetic transformation of green-coloured cotton. In Vitro Cellular \& Developmental Biology, v. 42, 439444, 2006. https://doi.org/10.1079/IVP2006777 